\title{
The Doctrine's Role in the Field of Legal Regulation of Public Relations: Problems and Prospects
}

\author{
Adel Abdullin ${ }^{1} \&$ Ainur Gilmullin ${ }^{2}$ \\ ${ }^{1}$ Law Faculty, Kazan Federal University, Russia \\ ${ }^{2}$ Legal Department, Kazan Federal University, Russia \\ Correspondence: Adel Abdullin, Kazan Federal University, Russia. E-mail: gilmullinainur@yandex.ru
}

Received: June 9, 2019

Accepted: August 25, $2019 \quad$ Online Published: August 31, 2019

doi:10.5539/jpl.v12n5p42

URL: https://doi.org/10.5539/jpl.v12n5p42

\begin{abstract}
The paper contains a comprehensive analysis of the legal doctrine's role in the field of legal regulation of public relations arising in modern public law practice. The theoretical and legal features of the legal doctrine are revealed. In particular, conclusions are drawn confirming the arguments that the legal doctrine allows building clear guidelines for the practice of lawmaking, enforcement of the right, and especially law enforcement and that the doctrine acts as a scientifically based criterion for the legitimacy, rationality, and effectiveness of states. Special attention is paid to the historical aspects of the legal doctrine development which have significance and influence on the formation and development of international and domestic law.

Particular attention of the authors of the paper is drawn to the place and role of legal doctrine in international legal practice. The paper notes that the legal doctrine manifestation in the activities of modern states can be observed in such functions as prognostic, evaluation, regulatory, methodological, world outlook and ideological function. In addition, it is noted that the doctrine plays an important role in the activities of the UN International Court of Justice, where the doctrines of the most qualified specialists are often used in making decisions and drawing up advisory opinions; in the development of international treaties at international conferences and in international organizations, etc. Specific examples of the legal doctrine manifestations in the activities of the ECHR are given.
\end{abstract}

Keywords: legal doctrine, public relations, international law, functions, source of law, UN, judicial practice

\section{Introduction}

In each historical period of the spiritual and metaphysical searches of people, a meaningful need is revealed for the generation of something creative and fundamental. As a result, thought is inevitably born, which becomes the determining vector of development for a certain historical period. Over time, ideas transform into a different, radically new form of doctrine which determines the further consideration of the fundamental principles of civilization and their broader interpretation encompassing spirituality, morality, legal consciousness and legal culture.

Considering the specifics of legal doctrine in the context of its manifestation in societies and states, it should be specially noted that a legal doctrine as such continuously develops and interacts not only with the legal sciences plane, but also with other humanitarian sciences, since the doctrine itself, even as a definition, is a certain complex of systematized and represented knowledge. The semantics of legal doctrine in the modern world is affected in various areas of legal regulation of both law enforcement and legislative processes. At the same time, the legislative process requires for its life not only legal categories and definitions but also fundamental provisions, development vectors, a methodological basis, fundamental and considered principles of law, which can only be obtained on the basis of legal doctrine.

Reforms and transformations that have taken place over the past two decades, both at the state (national) and interstate (international) levels are a visible result of the manifestation of a legal doctrine in legal regulation. The formation of states of the modern type cannot be imagined without legal doctrine. In particular, it is impossible to give a scientifically sound and socially expedient interpretation of normative legal acts, normative agreements, and other types of rulemaking without a doctrinally defined conceptual system. 


\section{Methods}

With the help of legal doctrine, the right and meaning of a particular legal construction become obvious, closer to the consciousness of not only public entities directly related to law-making and law enforcement but also of any private entity. Over the centuries-long evolution, legal doctrine has developed as a complex conceptual and semantic concept and system that accurately and deeply reflects the realities of social and legal practice. In this regard, the doctrine is designed to promote understanding of the content of the law, especially in a difficult legal and regulatory situation, the legal doctrine is not only ascertaining and descriptive in nature, but it is also a conductor of law in various practices of public life.

In the field of international law, the legal doctrine is able to manifest itself in the activities of modern states in its following functions, such as:

- Prognostic function - a legal doctrine is manifested in the process of development and justification of projects for reforming states and their institutions;

- Evaluation function - a legal doctrine is a criterion for the legitimacy and effectiveness of modern states

- Regulatory function - a legal doctrine governs the most complex situations and practices of states;

- Ideological and world outlook function - a legal doctrine forms the legal thinking and, in general, the legal consciousness of an individual and society, and also, at the interstate (international) level can form a single, concentrated and consensual knowledge in the field of law and its axiological features;

- Methodological function - a legal doctrine is manifested as the methodological basis of effective practical and scientific activity.

In the understanding of legal doctrine, the historical aspects of its development are of great importance; they have significance and influence on the formation and development of international and domestic law, as well as the state itself. Thus, in the history of the formation and development of law and the state, the foundations of legal doctrine were laid by ancient Greek thinkers in the form of general humanistic ideas. The further development of legal doctrine includes works by Roman lawyers of various historical periods (the period of the republic and the period of the empire), whose ideas were enshrined in legal practice in the form of edicts of masters and praetors; and represented a special doctrinal form of interpretation of laws by "experts in law". It is the edicts of the masters that were one of the forms of legal formation of Roman law. After a certain time period, the edicts acquired the significance of a program document. But, in addition to edicts, the Roman lawyer Gaius in his works highlighted other aspects of the doctrinal character. So, in the institutions, in the paragraph on "Civil Law and Natural Law" it was noted that "the civil law of the Roman people consists of laws, decisions of plebeians, decrees of the Senate, decrees of emperors, edicts of those officials who have the right to issue orders, and of the answers by connoisseurs (of rights)", and also that "edicts are the essence of the resolution and instructions of those officials who have the right to publish them. The right to issue edicts is granted to officials of the Roman people; however, in this respect of most importance are the edicts of two praetors - urban and Peregrine, whose jurisdiction in the provinces belongs to their governors. The same applies to edicts of the curule ediles, whose jurisdiction in the provinces of the Roman people belongs to quaestors...". All this once again testifies that the doctrinal awareness of law was generally inherent in the legal life of the Roman Empire and, therefore, to all subsequent world states that adopted this legal system. It must be emphasized that in the process of the transition from one socioeconomic formation to another, during the formation of states of different typologies, the doctrinal legal ideas about law, the state and its organization changed too; ideas about state-legal regulation were laid down as its foundation; all these factors and principles predetermined medieval legal doctrine.

In addition to the activities of Greek thinkers and Roman lawyers, the formation of a legal doctrine was influenced by medieval ideas about the need for the state to provide for people decent living conditions corresponding to human dignity (Thomas Aquinas), about the people as the only source of all power, the carrier of sovereignty and supreme legislator (Marsilius of Padua), etc.

The independent direction of the legal doctrine development as a source of transformations are the teachings of the Arab East, which have their own specifics about the legal regulation of public relations based on state legal concepts based on the holy canons of Muslim religious doctrine, in particular on the need for legislative establishment of ownership and property rights (Ibn Khaldun), and on the social nature of the state.

The legal doctrine of the Renaissance gave a whole constellation of rationalistic approaches based on progressive ideas about a sovereign state (J. Bodin), rule-based government (N. Machiavelli), equality (F. Bacon), and systematization of law (J. Althusius), etc. 
The Age of Enlightenment which was based on rationalism and free thought, is marked by doctrinal legal provisions that have made a significant contribution to the development of the theory and practice of natural human rights: the right to life, freedom, property (J. Locke), "social contract" (T. Hobbes), international law (G. Grotius), separation of powers (S. Montesquieu), equality of all before the law (Voltaire), legal statehood (I. Kant). In this period, the doctrinal pluralism was formed and the possibility of choosing certain points of view on the doctrine and its manifestation in social and legal practice was formed.

A legal doctrine as a source of law is the provisions, constructions, ideas, principles and judgments about law developed and substantiated by legal scholars, which are legally binding in various legal systems. Mandatory doctrinal legal provisions are commonly called "law of lawyers". The legal doctrine was the main source of continental European (Roman-German) law from the time of Roman law until the 19th century when the law took its place as the main source (state rule-making). But even after this, the legal doctrine remains one of the sources in the systems of the Romano-Germanic legal family. The legal doctrine as a source of law plays a significant and significant role in Muslim law. It has a certain legal value in common law systems.

\section{Results and Discussion}

The most important distinguishing feature of the legal doctrine manifestation in society and a state is that it can be implemented in a practical plane, in contrast to the scientific sphere, for which the main thing is "the truth of research" and realness of the results obtained. Legal doctrine does not pose a problem of truth, at the same time, as already noted, the legal doctrine should be recognized and determined, and its correctness or incorrectness should not be spoken about, however, since the legal doctrine is ideas and establishments that can, or cannot be tested in practice. This means that it is also possible to trace the development path and the correctness or incorrectness of assumptions and ideas in a doctrinal view. The actual recognition of legal doctrine is possible through its practical implementation, and its truthfulness is a topic for deeper study precisely in the doctrinal plane.

The significance of legal doctrine in the modern world is most affected in such areas of legal regulation as legal awareness, law enforcement and lawmaking.

As rightly noted in the scientific literature, the absence of a legal doctrine will only bring inconsistency for lawmaking and legal practice, legal theory, and legal life which will be formed for the implementation of short-term tasks, losing prospects and consistency in legal activity.

A legal doctrine based on national and international succession is manifested in the form of theoretical and legal knowledge, which contains legal constructions (fundamental and concrete theoretical ideas, conceptual provisions, principles, axioms). These structures reflect the laws of functioning of social and legal reality, including the specifics of the organization and functioning of the state mechanism; are tested in practice in the process of interaction based on the law of society and the state; are supported by the legal community; are enshrined in scientific texts; are partially legalized in the ideological norms of objective law (doctrines, strategies, concepts, programs, etc.), in the legal positions of national and international courts, documents of international law, codes of ethics, as well as documents on the development of strategy of society and the state.

Legal doctrine fills the legal system with systems of legal concepts, their definitions, disclosures the laws of legal logic. At the same time, the doctrine itself is influenced by external factors, both objective (a socio-economic situation, political course) and subjective in nature (authoritative opinions, personal conviction, the coordinated position of a number of subjects, compromises and conventionality regarding judgments).

According to its structure and characteristics, a legal doctrine can be considered as the prevailing ideological and theoretical knowledge and put on various official political, legal, planning and target documents (doctrines, strategies, concepts, programs, etc. ) containing constructions connected with the device and development of the state. It is this component of the legal doctrine that is directly manifested in the process of modernization and reform of the state during periods of instability of society.

Along with this, a legal doctrine contains scientifically based views on the remaining elements of the legal system, which are of a practical, applied and regulatory-communicative nature, contribute to the regulation of legal relations and affect the effectiveness of a state, both at the micro and macro levels.

The doctrine's role in the formation and development of international law is extremely important to us.

In the broad sense of the word, the doctrine in the field of international law is a system of views and concepts about the nature and purpose of international law in specific historical conditions. In the narrow sense, the doctrine is the scientific works by international lawyers. 
In accordance with paragraph 1 (d), Art. 38, the Statute of the International Court of Justice of the United Nations, the doctrine developed by the most qualified specialists in the international public law of various nations is used as an aid in determining legal norms.

The UN International Court of Justice quite often uses the doctrines of the most qualified specialists in making decisions and drawing up advisory opinions (they are used, first of all, in the opinions of judges and in the speeches of representatives of the parties).

References to the works of the most famous scientists are contained in the materials of international courts (for example, the ECHR, the Economic Court of the CIS, etc.), the tribunals, as well as in the reports of the UN International Law Commission; many of their members are professors and academic researchers in international law.

Of particular importance is the collective opinion of lawyers from different countries. In this regard, authoritative expert organizations such as the World Association of International Law, the Institute of International Law, the European Society of International Law, and the Russian Association of International Law play an important role in the development of international legal doctrinal provisions.

\section{Summary}

The doctrine contributes to the development of draft international treaties and resolutions of international organizations, the correct interpretation and application of international legal norms.

The doctrines develop and formulate new rules for international communication, which can become the norms of international law if they receive recognition of states in international treaties or international customs.

It should be noted that the work of lawyers plays a special role in the formation of international law. It was in these works that the very idea of its creation was expressed. Information on state practice that formed the norm was difficult to access. Therefore, diplomats and judges widely used works by theoreticians to prove the existence of certain norms. This situation gave the doctrine a significant opportunity to participate in the law-making process.

In the nineteenth and even the beginning of the twentieth centuries, many lawyers considered international law as "doctrinal" law to a large extent, "the law of scientists". They attributed to the science of international law not only a stating role but also the role of the creator of its norms. So, for example, J. Bluntschli called "a substitute for legislation" the international law courses, in which "law-knowing individuals set forth and systematize existing legal norms".

Nevertheless, it is undoubted that as the practice of states becomes more accessible as a result of the publication of various international and diplomatic documents, as well as decisions of international organizations and international courts, the role of the doctrine as a means of establishing the existence of international law and their interpretation have been obtaining a fairly obvious downward trend.

It should be noted that Art. 38 of the Statute of the International Court of the UN tells us only about the role of doctrine in the application of international law. But as far as the development of international law, here the situation is somewhat different. Practice shows that, for example, in matters of the progressive development of international law, the doctrine plays a significant role. The influence of the doctrine affects the determination of the positions of states in the development of international treaties at international conferences and in international organizations. Thus, the doctrine has a significant impact on the development of international law.

\section{Conclusions}

It should be emphasized that modern international judicial practice shows that legal doctrine is an auxiliary source of law, access to which occurs only in exceptional cases. Article 38 of the Statute of the UN International Court of Justice states: "A court that is obliged to resolve disputes submitted to it on the basis of international law shall apply:... judicial decisions and doctrines of the most qualified public law experts of various nations as an aid in determining legal norms". Thus, in the legal sense, the doctrine is not considered as a source of international law. It is only an auxiliary tool for determining legal norms. But this is very significant. If the doctrine is used at the law enforcement stage, then all the more for this at the law-making stage.

It is also interesting to refer to the practice of legal doctrine manifestation in the activities of the ECHR, which is confirmed by decisions taken by the judicial authority. Thus, in one of its rulings in the case of "Perincek v. Switzerland ", the ECHR notes that"... in relation to the denial of genocide, the German legal doctrine openly admits "Auschwitz's lies"; denial of other genocide manifestations also falls under Article 261 bis of the Criminal Code". In the case of Codarcea v. Romania, the ECPR states as follows: "In addition, by refusing to hold the hospital to civil liability, the domestic courts deprived the applicant of effective protection of her physical integrity, 
despite the fact that there were indications in the case-law of the highest courts of the country and in the legal doctrine of the fact that hospitals may be held responsible for the actions of doctors who are in labour relations with them. The applicant, whose right to indemnification has been recognized by the Romanian courts, had no remedy that can make this right effective." In the case of Jones and Others v. the United Kingdom, it is stated that: "The court referred to the decision of the House of Lords in the Pinochet case (No. 3) and to the increase in the number of exceptions to immunity ratione materiae, emphasized in the legal doctrine. It has acknowledged the existence of a controversial point as to whether unlawful acts could be considered as official actions for the purpose of this immunity. It has concluded that the legal doctrine and judicial practice no longer unanimously confirmed that residual immunity ratione materiae would extend to all acts committed during the course of one's job when allegations of serious human rights violations were made."

Quite pragmatic is the approach to appeal to the legal doctrine in the United States. So, according to some authors, one of the most effective and widespread mechanisms for the participation of doctrinal opinions in decisions of the US Supreme Court was the Institute of Amicus curiae ("friends of the court"). The specified institution received official fixation in the US Army Statute. In practice, the level of public awareness and interest in the dispute under consideration matters, the higher the level, the more representatives of the so-called "friends of the court" are invited to express their expert opinions and conclusions on specific issues. According to modern statistics, the US Armed Forces accept up to $90 \%$ of all considered cases taking into account the positions of "friends of the court".

Often, US courts, including the US Armed Forces, when administering justice, turn to other auxiliary, doctrinal sources of law, such as legal dictionaries, legal encyclopedias, and legal annotated reports (Annotated Law Reports), legal periodicals, legal treatises, books and textbooks, case law, legal catalogues.

\section{Acknowledgements}

The work is performed according to the Russian Government Program of Competitive Growth of Kazan Federal University.

\section{References}

Aquinas, T. (1901). Summa Theologica. Taurini, vol. 1-6.

Bodin, J. (1579). Les six livres de la République. P.: par J. DuPuys.

Demidov, A. I. (2001). Russian Legal Doctrine in the 21st Century: Problems and Ways to Solve Them: Scientific and Practical Conference. Saratov: Publishing House of the Saratov State Academy of Law.

ECtHR judgment dd. 01/14/2014 "Jones and Others v. The United Kingdom" case (complaints Nos. 34356/06 and 40528/06).

ECtHR judgment dd. 10/15/2015, "Perincek v. Switzerland" case (complaint No. 27510/08) The case is being prosecuted for public statements denying the legal characterization of the atrocities committed by the Ottoman Empire against the Armenian people in 1915 as "genocide" "The case has violated the requirements of Article 10, the Convention for the Protection of Human Rights and Fundamental Freedoms.

Emelin, M. Yu. (2015). Legal doctrine in the system of sources of common law: based on an analysis of the US legal system: a dissertation for the degree of candidate of legal sciences. Penza.

Gilmullin, A. R. (2019). Legal doctrine in the mechanism of the Russian state (theory and practice): monograph. M.: INFRA-M.

Information on the ECtHR judgment dd. 02.06.2009 in the case of Codarcea v. Romania (complaint No. $31675 / 04)$. The case is appealing against the lack of funds to compensate for health damage due to a medical mistake made in a state hospital. The case has violated the requirements of Article 8, the Convention for the Protection of the Human Rights and Fundamental Freedoms.

Jones, A. H. M. (1997). The Decline of the Ancient World. L.: Addison Wesley Longman Limited.

Kalamkaryan, R. A. (2006). The place of the doctrines by the most qualified specialists in the public law of various nations in the source base of modern international law. State and Law, (4), 78-86.

Locke, J. (2003). Two Treatises of Government. Cambridge: Cambridge University Press.

Lukashuk, I. I. (1996). International law. A common part. Textbook. - M.: Publishing House BEK.

Marsilius de Padua. Defensor pacis. (1933). Monuments Germaniae Historicis, Fontes iuris germanici antique. Hannover: Hahnsche Buchhandlung.

Nikolaev, B. V., \& Emelin, M. Yu. (2012). The concept of legal doctrine in the legal system of the United States. 
Izvestiya PSPU named after V. G. Belinsky.

Tunkin, G. I. (Ed.). (1994). International law: Textbook. M.: Legal literature.

\section{Copyrights}

Copyright for this article is retained by the author(s), with first publication rights granted to the journal.

This is an open-access article distributed under the terms and conditions of the Creative Commons Attribution license (http://creativecommons.org/licenses/by/4.0/). 